\title{
Wybrane zagadnienia z zakresu dostępu do informacji publicznej w samorządzie terytorialnym
}

Zagwarantowane w art. 61 Konstytucji $\mathrm{RP}^{1}$ prawo dostępu do informacji publicznej stanowi niewątpliwie jeden z filarów rozwoju społeczeństwa obywatelskiego. Społeczeństwo takie charakteryzuje się dużą świadomością i aktywnością obywatelską w życiu publicznym. Powyższy przepis gwarantuje każdemu obywatelowi prawo do uzyskiwania informacji o działalności organów władzy publicznej oraz osób pełniących funkcje publiczne. Prawo to obejmuje również uzyskiwanie informacji o działalności organów samorządu gospodarczego i zawodowego oraz innych osób i jednostek organizacyjnych w zakresie, w jakim wykonują one zadania władzy publicznej i gospodarują mieniem komunalnym lub majątkiem Skarbu Państwa. W świetle art. 61 Konstytucji RP prawo do uzyskiwania informacji publicznej obejmuje dostęp do dokumentów oraz wstęp na posiedzenia kolegialnych organów władzy publicznej pochodzących z powszechnych wyborów, z możliwością rejestracji dźwięku lub obrazu.

Zasady dostępu do informacji publicznej zostały rozwinięte przez ustawodawcę w przepisach ustawy o dostępie do informacji publicznej ${ }^{2}$, która w sposób ogólny określa zasady mające służyć praktycznej realizacji prawa dostępu do informacji publicznej, w tym trybu jej udzielania.

W związku z bezsprzecznym w ostatnich latach rozwojem świadomości obywatelskiej oraz zwiększeniem zainteresowania społeczeństwa działalnością organów samorządu terytorialnego nastąpił znaczny wzrost liczby składanych przez obywateli wniosków o udostępnienie informacji publicznej. W toku stosowania przepisów dotyczących prawa dostępu do informacji publicznej organy samorządu terytorialnego natrafiają na wiele problemów i wątpliwości interpretacyjnych. $Z$ uwagi na ich mnogość tylko niektóre z tych problematycznych zagadnień zostaną przedstawione w niniejszym opracowaniu.

1 Konstytucja RP z dnia 2 kwietnia 1997 r., Dz.U. nr 78 poz. 483 z późn. zm.

2 Ustawa z dnia 6 września 2001 r. o dostępie do informacji publicznej, t.j. Dz.U. 2015 poz. 2058 z późn. zm.; dalej u.d.i.p. 
Organy jednostek samorządu terytorialnego (zarówno wykonawcze, jak i stanowiąco-kontrolne), będące bezsprzecznie organami władzy publicznej, są podmiotami zobowiązanymi, na gruncie przepisów u.d.i.p., do udostępniania informacji publicznej. Jak stanowi bowiem art. 4 ust. 1 pkt 1 u.d.i.p., obowiązane do udostępniania informacji publicznej są władze publiczne oraz inne podmioty wykonujące zadania publiczne, w szczególności organy władzy publicznej. W związku z tym przepisem podmiotami zobowiązanymi do udostępniania informacji publicznej znajdującej się $\mathrm{w}$ ich posiadaniu będą nie tylko organy jednostek samorządu terytorialnego, ale również organy związków tychże jednostek, a więc związków międzygminnych, związków powiatowych, związków powiatowo-gminnych oraz związków metropolitalnych.

$\mathrm{Na}$ początku opracowania zostanie zaprezentowana problematyka formy, w jakiej powinien zostać złożony wniosek o udostępnienie informacji publicznej, a zwłaszcza problematycznej dla niektórych organów samorządu terytorialnego formy elektronicznej. Następnie zostaną omówione zagadnienia dotyczące dopuszczalności stosowania wzoru wniosku o udostępnienie informacji publicznej oraz cennika udostępniania tych informacji. Z uwagi na to, że wiele problemów stwarza udostępnianie informacji przetworzonych, zwłaszcza takich, które muszą dodatkowo zostać zanonimizowane, na zakończenie zostanie omówione również to zagadnienie.

\section{Pojęcie informacji publicznej}

Rozważania na temat wybranych problemów, z jakimi borykają się organy samorządu terytorialnego, z zakresu dostępu do informacji publicznej należy rozpocząć od wyjaśnienia, czym jest informacja publiczna. Zgodnie $z$ art. 1 ust. 1 u.d.i.p. informacja publiczną jest każda informacja o sprawach publicznych. Przykładowy katalog informacji stanowiących informację publiczną zawarty został przez ustawodawcę w art. 6 u.d.i.p. Zgodnie z tym przepisem udostępnianiu podlega w szczególności informacja publiczna o polityce wewnętrznej i zagranicznej (pkt 1), władzach publicznych i innych podmiotach wykonujących zadania publiczne, zwłaszcza o ich statusie prawnym, majątku publicznym, organizacji, przedmiocie działalności, kompetencjach, majątku, którym dysponują (pkt 2) oraz o zasadach ich funkcjonowania (pkt 3), danych publicznych, w tym w szczególności treści i postaci dokumentów urzędowych, np. aktów administracyjnych i innych rozstrzygnięć (pkt 4) oraz majątku publicznym (pkt 5).

Analiza przedstawionych przepisów prowadzi do jednoznacznego wniosku, że ustawodawca nie zdecydował się na wskazanie klasycznej, odsyłającej do cech istotnych definicji „informacji publicznej”. Pomocne w tym zakresie staje się orzecznictwo, zwłaszcza sądów administracyjnych, gdzie wskazuje się, że rozważania nad tym pojęciem należy prowadzić z uwzględnieniem wspomnianego art. 61 Konstytucji RP, a zwłaszcza jego 
ust. 1, zaś samo pojęcie musi być rozumiane szeroko3. Sądy administracyjne wskazują przy tym, że informacją publiczną jest każda wiadomość wytworzona przez szeroko rozumiane władze publiczne, a także inne podmioty sprawujące funkcje publiczne w zakresie wykonywania przez nie zadań publicznych i gospodarowania mieniem komunalnym lub mieniem Skarbu Państwa. Informacją publiczną jest również informacja niewytworzona przez wskazane podmioty, lecz do nich się odnosząca. Innymi słowy, informację publiczną stanowi treść wszelkiego rodzaju dokumentów - nie tylko bezpośrednio zredagowanych i wytworzonych przez wskazany podmiot - a więc także treść dokumentów, których używa on do zrealizowania powierzonych mu prawem zadań. Jednocześnie bez znaczenia jest, w jaki sposób dokumenty znalazły się w posiadaniu adresata wniosku o udostępnienie informacji publicznej, oraz to, czy znajdują się one w posiadaniu innego podmiotu, bowiem ważne jest jedynie to, by dokumenty takie służyły realizowaniu zadań publicznych przez adresata wniosku i odnosiły się do niego bezpośrednio ${ }^{4}$.

\section{Elektroniczny wniosek o udostępnienie informacji publicznej}

$\mathrm{Z}$ uwagi na to, że przepisy u.d.i.p. nie regulują kwestii formy, jaką powinien przybrać wniosek o udostępnienie informacji publicznej, zagadnienie to rodzi wiele problemów $\mathrm{w}$ praktyce funkcjonowania jednostek samorządu terytorialnego. Istotne z punktu widzenia możliwości udostępniania informacji publicznej na wniosek złożony drogą elektroniczną jest wskazanie, kto może być wnioskodawcą (nadawcą) takiego wniosku. W myśl art. 2 ust. 1 u.d.i.p. prawo dostępu do informacji publicznej przysługuje każdemu. Ponadto w ust. 2 tego przepisu ustawodawca wskazał, że od osoby wykonującej prawo do informacji publicznej nie wolno żądać wykazania interesu prawnego lub faktycznego. Przyrównując powyższe przepisy do art. 61 ust. 1 Konstytucji RP, wskazać należy, że na gruncie u.d.i.p. zakres podmiotowy prawa dostępu do informacji publicznej został rozszerzony w stosunku do regulacji konstytucyjnych, gdzie prawo do uzyskiwania informacji o działalności organów władzy publicznej oraz osób pełniących funkcje publiczne zostało przyznane obywatelom. Tym samym należy wskazać, że prawo dostępu do informacji publicznej przysługuje każdej osobie fizycznej bez względu na obywatelstwo, a pod pojęciem „każdy” należy rozumieć również osoby prawne oraz jednostki organizacyjne niebędące osobami prawnymi, o których mowa w art. $33^{1}$ Kodeksu cywilnego ${ }^{5}$. Bez znaczenia jest przy tym wiek osoby fizycznej - prawo to przysługuje również osobom niepełnoletnim - oraz posiadana zdolność do czynności prawnych - z wnio-

3 Cf. wyrok NSA z dnia 17 września 2014 r., sygn. I OSK 46/14; wyrok NSA z dnia 1 października 2014 r., sygn. I OSK 358/14; oba dostępne w Centralnej Bazie Orzeczeń Sądów Administracyjnych (CBOSA) - www.orzeczenia.nsa.gov.pl.

4 Cf. wyrok NSA z dnia 18 listopada 2013 r., sygn. I OSK 1558/13, CBOSA.

5 Ustawa z dnia 23 kwietnia 1964 r. - Kodeks cywilny, t.j. Dz.U. 2014 poz. 121 z późn. zm. 
skiem o udostępnienie informacji publicznej może wystąpić nie tylko osoba posiadająca pełną zdolność do czynności prawnych, ale również posiadająca zdolność ograniczoną lub w ogóle jej nieposiadająca.

Przechodząc do dopuszczalności stosowania elektronicznej formy wniosku o udostępnienie informacji publicznej, należy wskazać, że zgodnie z art. 10 ust. 1 u.d.i.p. informacja publiczna, która nie została udostępniona w Biuletynie Informacji Publicznej lub centralnym repozytorium, jest udostępniana na wniosek. $\mathrm{O}$ ile bezsprzeczne jest, że wniosek taki może przybrać tradycyjną formę pisemną, o tyle należałoby rozważyć możliwość zastosowania innej jego formy, np. elektronicznej.

Mając na uwadze konstytucyjne uregulowania prawa dostępu do informacji publicznej oraz zakres podmiotowy tego prawa i odformalizowaną procedurę udostępniania informacji publicznej, należy wskazać, że wniosek o udostępnienie informacji publicznej może przybrać formę nie tylko tradycyjną pisemną, ale również elektroniczną w następujących postaciach:

- za pomocą Elektronicznej Skrzynki Podawczej (ESP) na Elektronicznej Platformie Usług Administracji Publicznej (upup),

- opatrzony kwalifikowanym podpisem elektronicznym,

- w drodze zwykłej wiadomości e-mail.

O ile możliwość składania wniosków w dwóch pierwszych formach elektronicznych wydaje się bezsprzeczna, to już w przypadku trzeciej z nich w praktyce funkcjonowania jednostek samorządu terytorialnego pojawia się wiele wątpliwości i kontrowersji. Wątpliwości te rozwiewa orzecznictwo sądów administracyjnych, gdzie w sposób jednoznaczny przesądza się o dopuszczalności stosowania tej formy wniosku. Jak wskazuje bowiem w jednym ze swoich wyroków Naczelny Sąd Administracyjny:

[...] za wniosek pisemny uznawać należy również przesłanie zapytania pocztą elektroniczną nawet gdy nie zostanie użyty podpis elektroniczny. Pogląd ten wydaje się uzasadniony brakiem konieczności pełnego zidentyfikowania wnioskodawcy, a to z uwagi na to, że żądając informacji, nie musi się on wykazać jakimkolwiek interesem prawnym lub faktycznym, aby otrzymać informację. Wniosek o udzielenie informacji publicznej może przybrać każdą formę, o ile wynika z niego, co jest przedmiotem wniosku. Wniosek taki wszczyna postępowanie w sprawie, ale na tym etapie nie mają jeszcze zastosowania przepisy k.p.a. ${ }^{6}$

Analiza orzecznictwa sądów administracyjnych w powyższym zakresie prowadzi do konkluzji, że wniosek o udostępnienie informacji publicznej nie tylko może być składany poprzez przesłanie go pocztą elektroniczną (za pomocą wiadomości e-mail), ale

6 Wyrok NSA z dnia 16 marca 2009 r., sygn. I OSK 1277/08, CBOSA. 
że taki wniosek nie musi posiadać nawet podpisu osoby go składającej (wnioskodawcy), tj. jej imienia i nazwiska. Sądy uzasadniają to faktem, że konstytucyjne prawo dostępu do informacji publicznej, rozwinięte przepisami u.d.i.p., ma charakter powszechny, co oznacza, że prawo to przysługuje każdemu, bez konieczności spełnienia jakichkolwiek przesłanek w tym zakresie. Podanie natomiast stosownych danych osobowych będzie niezbędne dopiero w przypadku, gdy zaistnieje konieczność wydania decyzji administracyjnej z uwagi na odmowę udostępnienia informacji publicznej bądź umorzenie postępowania o udostępnienie informacji w przypadku określonym w art. 14 ust. 2 u.d.i.p. ${ }^{7}$

W związku z tym należy wskazać, że wniosek o udostępnienie informacji publicznej może zostać złożony również w formie zapytania wystosowanego drogą elektroniczną, i to nawet w sytuacji, gdy do jego autoryzacji nie użyto podpisu elektronicznego. Należy zgodzić się z sądami administracyjnymi, które wskazują, że postępowanie w sprawie udzielenia informacji publicznej ma charakter uproszczony i odformalizowany, a wnioskodawca nie musi być nawet w żaden sposób w pełni zidentyfikowany. Jak stanowi bowiem art. 2 ust. 2 u.d.i.p., od osoby zadającej pytanie dotyczące spraw publicznych nie można żądać wykazywania ani interesu prawnego, ani interesu faktycznego ${ }^{8}$.

\section{Stosowanie wzoru wniosku o udostępnienie informacji publicznej}

Zgodnie $\mathrm{z}$ art. 10 ust. 1 u.d.i.p. informacja publiczna, która nie została udostępniona w Biuletynie Informacji Publicznej lub centralnym repozytorium, jest udostępniana na wniosek, chyba że - jak stanowi ust. 2 tego przepisu - informacja taka może być niezwłocznie udostępniona. $\mathrm{W}$ takim przypadku udostępnienie następuje $\mathrm{w}$ formie ustnej lub pisemnej bez pisemnego wniosku. W praktyce funkcjonowania samorządu terytorialnego bardzo często się zdarza, że podmioty zobowiązane do udostępniania informacji publicznych, znajdujących się w ich posiadaniu, publikują na swoich stronach internetowych lub na stronie Biuletynu Informacji Publicznej (BIP) wzór wniosku o udostępnienie informacji publicznej. Działanie takie budzi wiele wątpliwości, zwłaszcza w kontekście jego legalności.

W przywoływanych już wyrokach sądy administracyjne wskazywały, że wniosek o udostępnienie informacji publicznej, z uwagi na brak konieczności pełnego zidentyfikowania wnioskodawcy, może przybrać dowolną formę (np. ustną, zwykłą pisemną, pisemną elektroniczną), byle wynikało z jego treści w sposób jasny, co jest jego przed-

7 Cf. np. wyrok WSA w Warszawie z dnia 23 września 2009 r., sygn. II SAB/Wa 57/09; wyrok WSA w Gliwicach z dnia 24 lutego 2012 r., sygn. IV SAB/G1 75/11, oba dostępne w CBOSA.

8 Cf. np. wyrok WSA w Krakowie z dnia 6 marca 2012 r., sygn. II SAB/Kr 183/11; wyrok WSA w Łodzi z dnia 10 maja 2012 r., sygn. II SAB/Łd 46/12, oba dostępne w CBOSA. 
miotem ${ }^{9}$. Oznacza to, że dla prawidłowości złożonego wniosku o udostępnienie informacji publicznej nie jest wymagane podanie nawet takich danych, jak imię i nazwisko wnioskodawcy, a tym bardziej szczegółowych danych osobowych, takich jak: adres, numer PESEL czy numer telefonu, pod którym można skontaktować się z wnioskodawcą. Uzyskanie takich danych przez podmiot zobowiązany do udostępnienia informacji publicznej będzie bowiem stanowić przetwarzanie danych osobowych w rozumieniu ustawy o ochronie danych osobowych ${ }^{10}$. Zgodnie $z$ art. 7 pkt 2 tejże ustawy przetwarzaniem danych osobowych jest każde działanie polegające na wykonywaniu jakichkolwiek operacji na danych osobowych, takich jak: zbieranie, utrwalanie, przechowywanie, opracowywanie, zmienianie, udostępnianie i usuwanie. W tym kontekście należy również przytoczyć art. 23 ust. 1 pkt 2 tej ustawy, zgodnie z którym przetwarzanie danych dopuszczalne jest m.in. wtedy, gdy jest to niezbędne dla zrealizowania uprawnienia lub spełnienia obowiązku wynikającego z przepisu prawa.

Ponieważ jednak przepisy u.d.i.p. wyraźnie wskazują, że „każdemu” przysługuje prawo dostępu do informacji publicznej, a od osoby wykonującej to prawo nie wolno żądać wykazania interesu prawnego lub faktycznego, to uzyskanie przez podmiot zobowiązany do udostępnienia informacji publicznej, do którego kierowany jest wniosek, danych osobowych typu dane adresowe wnioskodawcy lub jego numer telefonu bądź też numer PESEL, nie jest „niezbędne dla zrealizowania uprawnienia lub spełnienia obowiązku wynikającego z przepisu prawa”. Podobne stanowisko zajął w jednym ze swoich wystąpień Generalny Inspektor Ochrony Danych Osobowych ${ }^{11}$.

Jak wskazują w swoich orzeczeniach sądy administracyjne, celem u.d.i.p. jest odformalizowanie i uproszczenie postępowania w sprawach udostępniania informacji publicznej. Ustawodawca nie zawarł bowiem w jej przepisach żadnych wymogów formalnych dotyczących wniosku, poza tym, że musi być on w formie pisemnej (chyba że, jak stanowi art. 10 ust. 2 u.d.i.p., informacja taka może być niezwłocznie udostępniona - wówczas udostępnienie następuje w formie ustnej lub pisemnej bez pisemnego wniosku). W związku z tym wniosek o udostępnienie informacji publicznej może przybrać każdą formę, o ile wynika $z$ niego w sposób jasny, co jest jego przedmiotem. Oznacza to, że nakaz stosowania jedynego „słusznego” formularza wniosku czy też żądanie złożenia wniosku na opracowanym przez organ formularzu nie znajduje podstaw w obecnie obowiązujących przepisach prawa ${ }^{12}$.

9 Cf. np. wyrok NSA z dnia 16 marca 2009 r., sygn. I OSK 1277/08, CBOSA.

10 Ustawa z dnia 29 sierpnia 1997 r. o ochronie danych osobowych, t.j. Dz.U. 2015 poz. 2135 z późn. zm.

11 Cf. wystąpienie GIODO nr DOLiS-035-1241/14 z dnia 18 czerwca 2014 r. do Urzędu Gminy w sprawie dostosowania do ustawy o ochronie danych osobowych wniosku o udostępnienie informacji publicznej, http://www.giodo.gov.pl/plik/id_p/6600/j/p1/ [dostęp: 31.03.2016].

12 Cf. np. wyrok WSA w Opolu z dnia 5 sierpnia 2014 r., sygn. II SAB/Op 44/14, CBOSA. 
Odmiennie ustawodawca uregulował przypadki występowania $\mathrm{z}$ wnioskiem o ponowne wykorzystywanie informacji publicznej - w art. 23g ust. 13 u.d.i.p. wyraźnie bowiem zostało wskazane, że wzór takiego wniosku określa, w drodze rozporządzenia, minister właściwy do spraw informatyzacji ${ }^{13}$. Wzór taki został określony w rozporządzeniu z dnia 17 stycznia 2012 r. $^{14}$

Podsumowując, należy wskazać, że choć w większości przypadków intencje podmiotów zobowiązanych do udostępnienia informacji publicznej, które tworzą wzory takich wniosków, są słuszne, bowiem ich działania mają na celu uproszczenie procedury występowania przez obywateli (i nie tylko) o udostępnienie informacji publicznej, muszą się one liczyć z możliwością zakwestionowania takiego działania, czy to przez organy nadzoru, czy przez sądy administracyjne, z uwagi na brak podstaw prawnych takiego działania.

\section{Stosowanie cennika udostępniania informacji publicznej}

Najczęstszą nieprawidłowością w funkcjonowaniu organów jednostek samorządu terytorialnego w zakresie udostępniania informacji publicznej jest obciążanie wnioskodawców dodatkowymi kosztami udostępniania tychże informacji w oparciu o ustanowione przez siebie cenniki.

Jak stanowi art. 7 ust. 2 u.d.i.p., dostęp do informacji publicznej jest bezpłatny, z zastrzeżeniem art. 15 u.d.i.p. Przepis ten, będący wyjątkiem od zasady bezpłatności udostępniania informacji publicznej, stanowi w ust. 1, że jeżeli w wyniku udostępnienia informacji publicznej na wniosek podmiot obowiązany do udostępnienia ma ponieść dodatkowe koszty związane ze wskazanym we wniosku sposobem udostępnienia lub koniecznością przekształcenia informacji w formę wskazaną we wniosku, to podmiot ten może pobrać od wnioskodawcy opłatę w wysokości odpowiadającej tym kosztom. W ust. 2 tego przepisu wskazano z kolei, że podmiot zobowiązany do udostępnienia informacji publicznej, w terminie 14 dni od dnia złożenia wniosku, ma obowiązek powiadomić wnioskodawcę o wysokości opłaty. Udostępnienie informacji zgodnie z wnioskiem następuje po upływie 14 dni od dnia powiadomienia wnioskodawcy, chyba że

$13 \mathrm{Z}$ dniem 16 czerwca 2016 r. przepis ten, razem z całym rozdziałem 2a u.d.i.p. dotyczacym ponownego wykorzystywania informacji publicznej zostanie uchylony w związku $z$ wejściem w życie ustawy z dnia 25 lutego 2016 r. o ponownym wykorzystywaniu informacji sektora publicznego (Dz.U. poz. 352). W nowych przepisach ustawodawca zrezygnował z zawarcia upoważnienia do określenia wzoru wniosku o ponowne wykorzystywanie informacji sektora publicznego poprzestając na wskazaniu w art. 21 tejże ustawy wymogów formalnych, jakie powinno spełniać takie pismo.

14 Rozporządzenie Ministra Administracji i Cyfryzacji z dnia 17 stycznia 2012 r. w sprawie wzoru wniosku o ponowne wykorzystywanie informacji publicznej, Dz.U. poz. 94. 
wnioskodawca dokona w tym terminie zmiany wniosku w zakresie sposobu lub formy udostępnienia informacji albo wycofa wniosek.

Analiza powyższych przepisów wskazuje, że co do zasady dostęp do informacji publicznej ma charakter powszechny i bezpłatny, a w wyjątkowych sytuacjach podmiot zobowiązany do udostępnienia informacji publicznej może żądać od wnioskodawcy uiszczenia stosownej opłaty. Co ważne, samo pobieranie opłat ma charakter fakultatywny. Innymi słowy, podmiot zobowiązany może - ale nie musi - tego robić.

Dodatkowe koszty, o których mowa w art. 15 u.d.i.p., można podzielić na rzeczowe i osobowe. Kosztami rzeczowymi będą np. koszty związane z wykorzystanymi na potrzeby udostępnienia materiałami typu papier, płyta CD itp. Jak wskazuje się w orzecznictwie sądowoadministracyjnym, niedopuszczalne jest np. naliczanie opłaty za zużycie energii przez komputer wraz z urządzeniem skanującym ${ }^{15}$. Kosztami osobowymi są z kolei np. koszty związane $z$ wynagrodzeniem osoby przygotowującej odpowiedź na złożony wniosek o udostępnienie informacji publicznej. Jednakże sądy administracyjne wskazują, że niedopuszczalne jest żądanie opłaty z tytułu konieczności wykonywania dodatkowej pracy przez pracownika podmiotu zobowiązanego w godzinach jego pra$\mathrm{cy}^{16}$. Analizując orzecznictwo sądów administracyjnych w tym zakresie można byłoby wyprowadzić wniosek, że dopuszczalne będzie żądanie opłaty np. z tytułu konieczności wykonywania dodatkowej pracy przez pracownika po godzinach jego pracy, za które podmiot zobowiązany musiałby tejże osobie zapłacić jako nadgodziny. Jak wskazuje się bowiem w judykaturze sądowoadministracyjnej, praca pracownika, która jest związana z przygotowaniem żądanej informacji w godzinach jego pracy, stanowi podstawowy wyraz funkcjonowania organu, który ponosi koszty, wykonując swoje ustawowe zadania ${ }^{17}$.

Co ciekawe, w praktyce zdarzają się również sytuacje, kiedy to podmiot zobowiązany do udostępnienia informacji publicznej obciąża wnioskodawcę dodatkowymi kosztami, mimo że nie poniósł tych kosztów. Takie działanie uznawane jest w orzecznictwie sądów administracyjnych za niedopuszczalne, bowiem opłatę za udostępnienie informacji publicznej można pobrać wyłącznie wtedy, gdy podmiot zobowiązany rzeczywiście poniesie dodatkowe koszty ${ }^{18}$.

Przechodząc do problematyki możliwości uchwalania cenników udostępniania informacji publicznej należy wskazać, ̇̇e w piśmiennictwie w sposób jednoznaczny wyrażany jest pogląd, iż niedopuszczalne jest odgórne określanie ryczałtowych stawek za udostępnianie informacji publicznej ${ }^{19}$. Również sądy administracyjne wskazują, że wyznaczanie

15 Cf. np. wyrok WSA w Kielcach z dnia 12 grudnia 2012 r., sygn. II SA/Ke 755/12, CBOSA.

16 Cf. np. wyrok WSA w Warszawie z dnia 8 lipca 2010 r., sygn. II SAB/Wa 113/10, CBOSA.

17 Cf. np. wyrok WSA w Szczecinie z dnia 24 stycznia 2008 r., sygn. II SA/Sz 1006/07, CBOSA.

18 Cf. np. wyrok WSA w Łodzi z dnia 5 października 2012 r., sygn. II SA/Łd 824/12, CBOSA.

19 Cf. I. Kamińska, M. Rozbicka-Ostrowska, Ustawa o dostepie do informacji publicznej. Komentarz, Warszawa 2012, s. 201. 
opłaty za udostępnianie informacji publicznej w każdym przypadku wymaga indywidualnego rozpatrzenia ${ }^{20}$. Jednocześnie w orzecznictwie w sposób jednolity wyrażono pogląd, że ustalone koszty udostępnienia informacji publicznej muszą mieć charakter rzeczywisty ${ }^{21}$.

Mając to na uwadze, należy wskazać, że niedopuszczalne jest stosowanie przez organy jednostek samorządu terytorialnego cenników udostępniania informacji publicznej, bowiem stawki w nich określone mają charakter ryczałtowy, a nie rzeczywisty.

\section{Przetworzenie i anonimizacja informacji publicznej}

Kolejnym zagadnieniem z zakresu dostępu do informacji publicznej wzbudzającym w organach jednostek samorządu terytorialnego wątpliwości jest możliwość kwalifikowania zanonimizowanej informacji publicznej jako informacji przetworzonej.

Jak zostało wcześniej wskazane, podmiot zobowiązany do udostępnienia informacji publicznej nie ma prawa odmówić udostępnienia informacji publicznej ani żądać jakichkolwiek dodatkowych informacji od wnioskodawcy w zakresie czy to wykazania interesu faktycznego, czy też wykazania interesu prawnego, jeżeli wnioskowana przez niego informacja jest tzw. informacją prostą, czyli informacją, która znajduje się w posiadaniu podmiotu zobowiązanego, a udostępnienie jej nie wiąże się z zaangażowaniem dodatkowych sił czy środków osobowych lub finansowych, a jednocześnie informacja ta nie podlega ograniczeniom określonym w art. 5 ust. 1 i 2 u.d.i.p. Przepisy te wskazują na ograniczenia wynikające $z$ przepisów o ochronie danych osobowych, o ochronie informacji niejawnych oraz o ochronie innych tajemnic ustawowo chronionych. Ograniczenia te nie dotyczą jednak informacji o osobach pełniących funkcje publiczne, mających związek z pełnieniem tych funkcji oraz w przypadku gdy osoba fizyczna lub przedsiębiorca zrezygnują z przysługującego im prawa, o czym stanowi zdanie drugie w art. 5 ust. 2 u.d.i.p.

Z uwagi na to, że przepisy u.d.i.p. nie zawierają definicji „informacji przetworzonej”, pojęcie to zostało zdefiniowane w orzecznictwie sądów administracyjnych oraz piśmiennictwie. Zgodnie $z$ dominującym poglądem w tym zakresie informacją publiczną przetworzoną jest taka informacja, która została opracowana przez podmiot zobowiązany, przy użyciu dodatkowych sił i środków, na podstawie posiadanych przez niego danych, na podstawie kryteriów wskazanych przez wnioskodawcę. Innymi słowy, informacja przetworzona to informacja, która zostanie przygotowana „specjalnie” dla wnioskodawcy wedle wskazanych przez niego kryteriów, której wytworzenie wymaga intelektualnego zaangażowania podmiotu zobowiązanego ${ }^{22}$.

20 Cf. np. wyrok WSA w Poznaniu z dnia 12 września 2012 r., sygn. IV SA/Po 475/12, CBOSA. 21 Cf. np. wyrok WSA w Warszawie z dnia 8 września 2010 r., sygn. II SAB/Wa 113/10; wyrok WSA w Lublinie z dnia 8 kwietnia 2010 r., sygn. II SA/Lu 44/10, oba dostępne w CBOSA. 22 Cf. np. wyrok NSA z dnia 5 kwietnia 2013 r., sygn. I OSK 89/13, CBOSA. 
Oznacza to, że w przypadku gdy podmiot zobowiązany do udostępnienia informacji publicznej uzna, iż wnioskowana informacja posiada cechy „informacji przetworzonej”, ma obowiązek wezwania wnioskodawcy do wykazania, że uzyskanie przez niego danej informacji jest „szczególnie istotne dla interesu publicznego”. Jak wskazuje się w orzecznictwie sądów administracyjnych, informacja publiczna przetworzona to taka informacja, na którą składa się pewna suma tzw. informacji publicznej prostej, zwykle dostępnej bez wykazywania przesłanki interesu publicznego. Ze względu jednak na treść żądania udostępnienie wnioskodawcy konkretnej informacji publicznej, nawet o wspomnianym prostym charakterze, może się wiązać $z$ potrzebą przeprowadzenia odpowiednich analiz, zestawień, wyciągów, usuwania danych chronionych prawem. Takie zabiegi czynią informacje proste informacją przetworzoną, której udzielenie skorelowane jest z potrzebą wykazania przesłanki interesu publicznego ${ }^{23}$.

Również pojęcie „szczególnie istotnego interesu publicznego” nie zostało przez ustawodawcę zdefiniowane $\mathrm{w}$ przepisach u.d.i.p. Także w tym przypadku pomocne jest orzecznictwo sądów administracyjnych w zrozumieniu tego pojęcia. W judykaturze przyjęto, że pojęcie to odnosi się w swej istocie do spraw związanych z funkcjonowaniem państwa oraz innych ciał publicznych jako pewnej całości, szczególnie z funkcjonowaniem podstawowej struktury państwa. Skuteczne działanie w granicach interesu publicznego wiąże się z możliwością realnego wpływania na funkcjonowanie określonych instytucji państwa w szerokim tego słowa znaczeniu ${ }^{24}$. Sądy wskazują również, że wykładnia celowościowa art. 3 ust. 1 pkt 1 u.d.i.p. sprzeciwia się przyjęciu, że istotne jest nie tylko to, w jakim celu (szczególnie istotnym dla interesu publicznego) informacja publiczna ma być udostępniona, ale również to, kto się o nią ubiega. Gdyby ustawodawca chciał dać radnym, posłom lub innym osobom pełniącym funkcje publiczne prawo dostępu do informacji publicznej przetworzonej, nie wprowadzałby kryterium interesu publicznego. Poprzez użycie zwrotu „szczególnie istotne” ustawodawca wprowadził kwalifikowaną formę interesu publicznego, bowiem nie wystarczy, aby udzielenie informacji było istotne z punktu widzenia interesu publicznego, musi ono być jeszcze „szczególnie istotne”. Wnioskodawca musi więc wykazać, że informacje które zamierza uzyskać, nie dotyczą wyłącznie jego interesu, lecz że działa on w interesie publicznym ${ }^{25}$.

Przechodząc do pojęcia „anonimizacji” informacji publicznej, należy wskazać, że w orzecznictwie sądowoadministracyjnym występują rozbieżności w kwestii możliwości kwalifikowania jako informacji przetworzonej informacji publicznej poddanej czynnościom anonimizowania, która zawiera informacje objęte tajemnicą z mocy szczegółowego przepisu prawa. Zdaniem części orzecznictwa już dokonanie samego procesu

23 Cf. np. wyrok NSA z dnia 17 października 2006 r., I OSK 1347/05, CBOSA.

24 Cf. np. wyrok WSA w Warszawie z dnia 15 marca 2005 r., sygn. II SA/Wa 2225/04; wyrok WSA w Warszawie z dnia 17 maja 2005 r., sygn. II SA/Wa 481/05, oba dostępne w CBOSA.

25 Cf. np. wyrok NSA z dnia 16 czerwca 2009 r., sygn. I OSK 57/09, CBOSA. 
anonimizacji powoduje, że taka informacja publiczna staje się automatycznie informacją przetworzoną. Z kolei inna część orzecznictwa prezentuje odmienne stanowisko, zgodnie $z$ którym anonimizacja informacji prostej nie powoduje powstania jakościowo nowej informacji, tj. informacji przetworzonej, gdyż usunięcie danych osobowych jest tylko przekształceniem informacji prostej i nie wymaga żadnego wysiłku intelektualnego ze strony podmiotu zobowiązanego do jej udostępnienia.

Co do zasady, wydaje się, że drugi z ww. poglądów jest właściwy, a więc pogląd, zgodnie $z$ którym sam proces anonimizacji danych osobowych, czy też innych informacji niejawnych, nie powoduje automatycznie wytworzenia jakościowo nowej informacji przetworzonej, co jednocześnie miałoby skutkować koniecznością wykazania przez wnioskodawcę szczególnie istotnego interesu publicznego. Jak wskazują sądy administracyjne, informacja prosta nie zmienia się $\mathrm{w}$ informację przetworzoną poprzez samo dokonanie procesu anonimizacji, bowiem czynność ta polega jedynie na jej przekształceniu, a nie przetworzeniu $^{26}$. O przetworzeniu informacji nie stanowi również sięganie do materiałów archiwalnych. Wytworzenie informacji przetworzonej wymaga bowiem przeprowadzenia przez podmiot zobowiązany pewnych czynności analitycznych, organizacyjnych $\mathrm{i}$ intelektualnych na podstawie posiadanych informacji prostych.

Do powyższej tezy należy jednak wskazać pewne zastrzeżenia, kiedy dopuszczalne będzie potraktowanie procesu anonimizacji jako wystarczającej przesłanki do uznania danej informacji publicznej za informację przetworzoną w rozumieniu przepisów u.d.i.p., bowiem nie w każdym przypadku organ zobowiązany do udostępnienia informacji publicznej będzie miał do czynienia $\mathrm{z}$ żądaniem udostępnienia informacji wymagającej zastosowania prostego procesu anonimizacji, np. usunięcia danych osobowych w postaci imienia i nazwiska, numeru PESEL czy daty urodzenia, niewymagających szczególnego wysiłku intelektualnego bądź przygotowania ze strony zobowiązanego. Tym samym za wątpliwe należy uznać twierdzenia części sądów administracyjnych, generalizujących problem przetworzenia i anonimizacji informacji publicznej i wskazujących, że wyłączenie pewnych danych ze względu na ochronę informacji niejawnych, ochronę tajemnic ustawowo chronionych, prywatność osoby fizycznej czy tajemnicę przedsiębiorcy z treści udostępnianej informacji publicznej nie powoduje nadania tej informacji charakteru informacji przetworzonej ${ }^{27}$.

Uznanie, czy w określonym przypadku podmiot zobowiązany do udostępnienia informacji publicznej ma do czynienia $z$ informacją przetworzoną, wymaga analizy i indywidualnego podejścia. $Z$ dużym prawdopodobieństwem można bowiem stwierdzić, że w wielu przypadkach żądanie udostępnienia określonych informacji publicznych będzie sformułowane w sposób, który będzie nakazywać ograniczenie przez podmiot

26 Cf. np. wyrok NSA z dnia 9 sierpnia 2011 r., sygn. I OSK 792/11, CBOSA. 27 Cf. np. wyrok WSA w Poznaniu z dnia 7 marca 2013 r., sygn. II SA/Po 47/13, CBOSA. 
zobowiązany pełnego, niczym nieskrępowanego dostępu do informacji poprzez konieczność zanonimizowania określonych informacji, co dodatkowo może być poprzedzone koniecznością dokonania stosownych analiz. Bez trudu można wyobrazić sobie sytuację, w której udostępnienie żądanej informacji może wiązać się z koniecznością dokonania anonimizacji informacji wynikających chociażby np. z tajemnicy adwokackiej, radcowskiej, notarialnej, lekarskiej, bankowej czy ubezpieczeniowej. W takim przypadku przeprowadzenie anonimizacji nie będzie bowiem polegało wyłącznie na zwykłym „zaczernieniu" danych osobowych, ale wymagać będzie dokonania zarówno odpowiednich analiz posiadanych treści, jak i posiadania przez podmiot bezpośrednio przygotowujący daną informację niezbędnej wiedzy pozwalającej wskazać, co podlega ochronie, a co nie.

W części orzecznictwa sądów administracyjnych słusznie wskazuje się, że w pewnych przypadkach szeroki zakres wniosku wymagający zgromadzenia, przekształcenia (zanonimizowania) i sporządzenia wielu kserokopii określonych dokumentów może wymagać takich działań organizacyjnych i angażowania środków osobowych, które zakłócają normalny tok działania podmiotu zobowiązanego i utrudniają wykonywanie przypisanych mu zadań. Informacja wytworzona w ten sposób, mimo że składa się z wielu informacji prostych będących w posiadaniu organu, powinna być uznana za informację przetworzoną, gdyż powstały w wyniku wskazanych wyżej działań zbiór nie istniał w chwili wystąpienia $z$ żądaniem o udostępnienie informacji publicznej ${ }^{28}$. W piśmiennictwie wskazuje się również, że wystąpienie przez wnioskodawcę z żądaniem udostępnienia wokand sądowych za jeden, konkretny miesiąc, mimo konieczności dokonania przez podmiot zobowiązany wyłącznie anonimizacji ich przed udostępnieniem, należy traktować jako przetworzenie informacji, a więc wytworzenie nowej, nieistniejącej wcześniej ${ }^{29}$.

\section{Podsumowanie}

Przeprowadzona analiza najczęstszych problemów, z jakimi borykają się organy jednostek samorządu terytorialnego w przedmiocie udostępniania informacji publicznej, mimo że stanowi niewielki fragment całej problematyki w tym zakresie, wskazuje na konieczność nie tylko doprecyzowania, ale w niektórych przypadkach również wyboru przez ustawodawcę prawidłowego rozumienia niektórych najbardziej problematycznych zagadnień. Wydawać by się mogło, że biorąc pod uwagę kilkanaście lat obowiązywania przepisów u.d.i.p. oraz bogate orzecznictwo sądów administracyjnych w tym zakresie, podmioty zobowiązane do udostępnienia informacji publicznej nie będą miały problemów z realizacją konstytucyjnego prawa dostępu do informacji publicznej. Praktyka

28 Cf. np. wyrok NSA z dnia 23 stycznia 2015 r., sygn. I OSK 315/14, CBOSA.

29 Cf. J. Drachal, Prawo do informacji publicznej w świetle wyktadni funkcjonalnej, [w:] Sadownictwo administracyjne gwarantem wolności i praw obywatelskich 1980-2005, red. J. Góral, R. Hauser, J. Trzciński, Warszawa 2005, s. 147. 
Wybrane zagadnienia z zakresu dostepu do informacji publicznej... $\mid 291$

pokazuje jednak, że bez ingerencji ustawodawcy w niektóre kwestie przedstawione w niniejszym opracowaniu problemy będą w dalszym ciągu przysparzać organom samorządu terytorialnego wielu trudności.

\section{Literatura}

Drachal J., Prawo do informacji publicznej w świetle wyktadni funkcjonalnej, [w:] Sadownictwo administracyjne gwarantem wolnosici i praw obywatelskich 1980-2005, red. J. Góral, R. Hauser, J. Trzciński, Warszawa 2005.

Kamińska I., Rozbicka-Ostrowska M., Ustawa o dostępie do informacji publicznej. Komentarz, Warszawa 2012.

Wyrok NSA z dnia 17 października 2006 r., I OSK 1347/05, CBOSA.

Wyrok NSA z dnia 16 marca 2009 r., sygn. I OSK 1277/08, CBOSA.

Wyrok NSA z dnia 16 czerwca 2009 r., sygn. I OSK 57/09, CBOSA.

Wyrok NSA z dnia 9 sierpnia 2011 r., sygn. I OSK 792/11, CBOSA.

Wyrok NSA z dnia 5 kwietnia 2013 r., sygn. I OSK 89/13, CBOSA.

Wyrok NSA z dnia 18 listopada 2013 r., sygn. I OSK 1558/13, CBOSA.

Wyrok NSA z dnia 17 września 2014 r., sygn. I OSK 46/14, CBOSA.

Wyrok NSA z dnia 1 października 2014 r., sygn. I OSK 358/14, CBOSA.

Wyrok NSA z dnia 23 stycznia 2015 r., sygn. I OSK 315/14, CBOSA.

Wyrok WSA w Gliwicach z dnia 24 lutego 2012 r., sygn. IV SAB/G1 75/11, CBOSA.

Wyrok WSA w Kielcach z dnia 12 grudnia 2012 r., sygn. II SA/Ke 755/12, CBOSA.

Wyrok WSA w Krakowie z dnia 6 marca 2012 r., sygn. II SAB/Kr 183/11, CBOSA.

Wyrok WSA w Lublinie z dnia 8 kwietnia 2010 r., sygn. II SA/Lu 44/10, CBOSA.

Wyrok WSA w Łodzi z dnia 10 maja 2012 r., sygn. II SAB/Łd 46/12, CBOSA.

Wyrok WSA w Łodzi z dnia 5 października 2012 r., sygn. II SA/Łd 824/12, CBOSA.

Wyrok WSA w Poznaniu z dnia 12 września 2012 r., sygn. IV SA/Po 475/12, CBOSA.

Wyrok WSA w Poznaniu z dnia 7 marca 2013 r., sygn. II SA/Po 47/13, CBOSA.

Wyrok WSA w Szczecinie z dnia 24 stycznia 2008 r., sygn. II SA/Sz 1006/07, CBOSA.

Wyrok WSA w Warszawie z dnia 15 marca 2005 r., sygn. II SA/Wa 2225/04, CBOSA.

Wyrok WSA w Warszawie z dnia 17 maja 2005 r., sygn. II SA/Wa 481/05, CBOSA.

Wyrok WSA w Warszawie z dnia 23 września 2009 r., sygn. II SAB/Wa 57/09, CBOSA.

Wyrok WSA w Warszawie z dnia 8 września 2010 r., sygn. II SAB/Wa 113/10, CBOSA.

Wyrok WSA w Opolu z dnia 5 sierpnia 2014 r., sygn. II SAB/Op 44/14, CBOSA.

Wystąpienie GIODO nr DOLiS-035-1241/14 z dnia 18 czerwca 2014 r. do Urzędu Gminy w sprawie dostosowania do ustawy o ochronie danych osobowych wniosku o udostępnienie informacji publicznej, http://www.giodo.gov.pl/plik/id_p/6600/j/pl/ [dostęp: 14.06.2016]. 
292 | Adam Mickiewicz University Law Review

\section{SUMMARY}

\section{Selected issues of access to public information in local government}

The right of access to public information is one of the fundamental constitutional civil rights in the Polish legal system. Its rules on practical implementation regulate the law of access to public information. With the increase of civic awareness among citizens there also follows a growth in applications for access to public information. This has caused a range of problems and doubts in interpretation, which local government bodies have to contend with when dealing with submitted applications. In this article the author presents the most common problems which local government bodies must face in practice.

Keywords: the right of access to public information, access to public information, public information, processed information, anonymization

Mateusz Karciarz, Adam Mickiewicz University Poznań, Faculty of Law and Administration, al. Niepodległości 53, 61-714 Poznań, e-mail: mateusz.karciarz@amu.edu.pl. 